\title{
The ADAMTS1 Protease Gene Is Required for Mammary Tumor Growth and Metastasis
}

\author{
Carmela Ricciardelli, ${ }^{*}$ Kate M. Frewin, ${ }^{*}$ \\ Izza de Arao Tan, ${ }^{*}$ Elizabeth D. Williams, ${ }^{\dagger}$ \\ Kenneth Opeskin, ${ }^{\ddagger}$ Melanie A. Pritchard, ${ }^{\S}$ \\ Wendy V. Ingman, ${ }^{*}$ and Darryl L. Russell* \\ From the School of Paediatrics and Reproductive Health,* \\ Robinson Institute, University of Adelaide, Adelaide; the Centre \\ for Cancer Research, ${ }^{\dagger}$ Monash Institute of Medical Research, \\ Monash University, Melbourne; the Department Anatomical

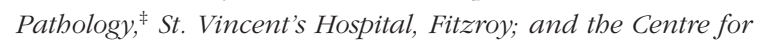 \\ Functional Genomics and Human Disease, ${ }^{\circledR}$ Monash Institute of \\ Medical Research, Monash University, Clayton, Australia
}

A disintegrin and metalloprotease with thrombospondin motifs protein 1 (ADAMTS1) is a protease commonly up-regulated in metastatic carcinoma. Its overexpression in cancer cells promotes experimental metastasis, but whether ADAMTS1 is essential for metastatic progression is unknown. To address this question, we investigated mammary cancer progression and spontaneous metastasis in the MMTV-PyMT mouse mammary tumor model in Adamts1 knockout mice. Adamts $1^{-/-} /$PyMT mice displayed significantly reduced mammary tumor and lung metastatic tumor burden and increased survival, compared with their wild-type and heterozygous littermates. Histological examination revealed an increased proportion of tumors with ductal carcinoma in situ and a lower proportion of high-grade invasive tumors in Adamts $1^{-/-} /$ PyMT mice, compared with Adamts $1^{+/+} /$PyMT mice. Increased apoptosis with unaltered proliferation and vascular density in the Adamts $1^{-/-} /$PyMT tumors suggested that reduced cell survival accounts for the lower tumor burden in ADAMTS1-deficient mice. Furthermore, Adamts1 ${ }^{-/-}$tumor stroma had significantly lesser amounts of proteolytically cleaved versican and increased numbers of $\mathrm{CD}^{4} 5^{+}$leukocytes. Characterization of immune cell gene expression indicated that cytotoxic cell activation was increased in Adamts $1^{-/-}$tumors, compared with Adamts $1^{+/+}$tumors. This finding is supported by significantly elevated $\mathrm{IL}^{-12}{ }^{+}$cell numbers in Adamts $^{-/-}$tumors. Thus, in vivo ADAMTS1 may promote mammary tumor growth and progression to metastasis in the
PyMT model and is a potential therapeutic target to prevent metastatic breast cancer. (Am J Pathol 2011, 179:3075-3085; DOI: 10.1016/j.ajpath.2011.08.021)

The A disintegrin and metalloprotease with thrombospondin motifs (ADAMTS) family of proteins is composed of extracellular metalloproteases, including ADAMTS1, originally identified in cachexigenic colon cancer cells., ${ }^{1,2}$ Mice with Adamts1-null mutation exhibit urogenital defects and female infertility because of impaired remodeling of ovarian extracellular matrix (ECM), but ovarian steroid production and lactation are normal. ${ }^{3-5} \mathrm{~A}$ range of ECM proteins have been identified as potential ADAMTS1 substrates, including collagens, ${ }^{6}$ nidogen, ${ }^{7}$ and syndecan $-4^{8}$; however, the proteoglycans versican and aggrecan have been consistently shown to be key ADAMTS1 targets. ${ }^{4,9,10}$ ADAMTS1 processing of versican is important in cell migration during wound healing, ${ }^{11}$ endothelial cell invasion, ${ }^{12}$ and remodeling of cardiac jelly ECM during heart morphogenesis. ${ }^{13}$ These observations indicate that ADAMTS1 mediates acute regulated tissue remodeling processes that occur in development and in adult reproductive tissues, but also in cancer growth and metastasis.

Emerging evidence associates ADAMTS1 expression with metastatic potential. Elevated expression of ADAMTS1 is characteristic of breast cancer cell lines ${ }^{14,15}$ and human breast cancers with high bone metastatic potential. ${ }^{16}$ Likewise, local invasion and lymph node metastasis of pancreatic cancer is associated with elevated Adamts 1. ${ }^{17}$ Overexpression of full-length ADAMTS1 in

Supported by a grant from the Australian National Health and Medical Research Council (NHMRC ID no. 519228 to D.L.R.), by Australian National Health and Medical Research Council Career Development Awards (NHMRC ID no. 349547 to D.L.R. and no. 519539 to E.D.W.), and by a Hilda Farmer Fellowship (C.R.) supported by University of Adelaide Medical Endowment Funds.

Accepted for publication August 26, 2011.

Supplemental material for this article can be found at http://ajp. amjpathol.org or at doi: 10.1016/j.ajpath.2011.08.021.

Address reprint requests to Darryl L. Russell, Ph.D., University of Adelaide, SPRH, Medical School, North Frome Rd., Adelaide, South Australia 5005, Australia. E-mail: darryl.russell@adelaide.edu.au. 
Chinese hamster ovary $(\mathrm{CHO})$ cells enhanced growth of tumor xenografts in nude mice, ${ }^{18}$ and overexpression of active ADAMTS1 promoted pulmonary metastasis of murine mammary carcinoma (TA3) and Lewis lung carcinoma cells, but catalytically inactive mutant ADAMTS1 prevented metastasis. ${ }^{19}$ Thus, the protease action of ADAMTS1 is predicted to participate in the ECM remodeling that promotes metastasis.

Versican, a large aggregating extracellular proteoglycan found in peritumoral stroma of many carcinoma types, is among the most consistent predictors of cancer relapse and poor survival. This was first reported in breast and prostate cancer, ${ }^{20-22}$ and it has been corroborated in at least 10 different carcinoma types. ${ }^{23}$ Proteolytic cleavage of versican by ADAMTS family proteases is emerging as a key morphogenic patterning event in development, ${ }^{24-26}$ with potent effects on cell survival and proliferation. We hypothesized that tumors expressing high levels of ADAMTS1 may proteolytically process versican and other substrates in the peritumoral environment to promote tumor progression.

To clarify the role of ADAMTS1 in mammary carcinogenesis and metastasis, we used the transgenic mouse mammary tumor virus polyoma middle T (MMTV-PyMT) model. Mammary epithelial cell hyperplasia is initiated by expression of the PyMT transgene, and tumors in this model spontaneously progress to metastatic disease, recapitulating multistage progression of the human disease. ${ }^{27}$ At the molecular level, this model is closely aligned with the basal subtype of human breast cancer. ${ }^{28}$ We found that advanced tumors acquired high Adamts 1 expression, which also positively correlated with tumor weight. We introduced Adamts1-null mutation into this model and found reduced primary tumor size and grade, as well as reduced metastatic burden, in Adamts $1^{-1-}$ mice, compared with wild-type $\mathrm{PyMT}^{+}$littermates. Apoptotic rate increased in Adamts $1^{-1-}$ tumor cells, suggesting that reduced tumor cell survival accounts for the smaller tumor size. ADAMTS-cleaved versican was elevated in Adamts $1^{+/+}$peritumoral stroma with no change in versican mRNA. Stromal leukocytes and $\mathrm{IL}-12^{+}$cell numbers were increased, and we identified a cytotoxic immune activation signature in Adamts $1^{-\prime-}$ tumors. The results provide evidence that ADAMTS1 has nonredundant actions in remodeling the tumor microenvironment involved in mammary tumor growth, progression to invasive grade, and subsequent pulmonary metastasis.

\section{Materials and Methods}

\section{Mouse Cohorts}

Male $\mathrm{PyMT}^{+} /$Adamts $^{+/-}$(FVB/N strain) mice were mated with Adamts $1^{+/-}$females (C57BL/6 strain). ${ }^{5}$ Their male $\mathrm{PyMT}^{+} /$Adamts $^{+/-}$or $\mathrm{PyMT}^{+} /$Adamts $1^{-/-}$offspring were mated with $\mathrm{PyMT}^{-} \mid$Adamts $1^{+/-}$females to generate the $\mathrm{PyMT}^{+}$Adamts $1^{+/+}(n=14)$, Adamts $1^{+/-}$ $(n=46)$, and Adamts1 ${ }^{-1-}(n=21)$ mice used in the present study. All pups were weaned at 21 days, and genotyped; all mice analyzed were virgin mice. Mice were monitored daily from weaning for the presence of palpable tumors, and mice were euthanized by cervical dislocation when a single tumor reached $>3.0 \mathrm{~cm}^{3}$ or at 20 weeks of age. Tumors were excised and weighed at the time of euthanasia. All animal procedures were approved by the University of Adelaide Animal Ethics Committee and were in accordance with the Australian code of practice for the care and use of animals for scientific purposes.

\section{Genotyping}

Genotyping was performed by PCR amplification using allele-specific primers and genomic DNA extracted from mouse tail biopsies digested using proteinase $\mathrm{K}$ and phenol/chloroform/isoamyl-extracted DNA. Identification of the MMTV-PyMT allele was performed using MMTVPyMT primers MMTV 490 (F) 5'-CGTCCAGAAAACCACAGTCA-3' and MMTV 685 (R) 5'-CCGCTCGTCACTTATCCTTC-3' (band size, 195 bp). PCR reaction conditions were $94^{\circ} \mathrm{C}$ (2 minutes), followed by 30 cycles of $94^{\circ} \mathrm{C}$ (30 seconds), $55^{\circ} \mathrm{C}$ (30 seconds), $72^{\circ} \mathrm{C}$ ( 1 minute), and $72^{\circ} \mathrm{C}$ (5 minutes).

The Adamts1 wild-type allele was identified by PCR using Adamts1 ex2 (F) 5'-AGTTACCTCCAATGCAGCTCTCA-3' and ex3 (R) 5'-ATCCCGAGAGTGTCACACGTGT-3' primers (band size, 576 bp). The Adamts 1 null allele was identified by a primer set spanning the deleted region of the Adamts 1 gene: (F) 5'-TCCTCAAGCCCCACCCCTTGG-3' and (R) 5'-TCCTGCTGGGGTCACATACAG-3' (band size, 1323 bp WT and 278 bp knockout). PCR reaction conditions were $94^{\circ} \mathrm{C}$ (5 minutes), followed by 30 cycles of $94^{\circ} \mathrm{C}$ (30 seconds), $60^{\circ} \mathrm{C}$ (30 seconds), $72^{\circ} \mathrm{C}$ ( 1.5 minutes), and $72^{\circ} \mathrm{C}$ (5 minutes). The PCR master mix ( $25 \mu \mathrm{L})$ contained $5 \mu \mathrm{L} 5 \times$ SYBR Green buffer (Promega, Madison, WI), $2.5 \mu \mathrm{L} \mathrm{MgCl}, 1 \mu \mathrm{L}$ dNTP, $1.25 \mu \mathrm{L}$ of each primer, $12.9 \mu \mathrm{L}$ water, $0.1 \mu \mathrm{L}$ Taq polymerase (Promega), and $1 \mu \mathrm{L}$ DNA.

\section{Tissue Collection and Processing}

Mammary tumors, lungs, and brachial and axillary lymph nodes were collected at euthanasia between 16 and 20 weeks of age. All mammary glands and their associated tumors were weighed, to obtain a measure of relative tumor burden normalized for total mouse weight. Tissue samples were fixed in $4 \%$ paraformaldehyde for 24 hours and then were processed and embedded in paraffin for sectioning and histological analysis. Lung and lymph node blocks were serially sectioned at $5 \mu \mathrm{m}$ thickness; a section every $100 \mu \mathrm{m}$ used for systematic analysis of each tissue was stained with H\&E for histomorphometric

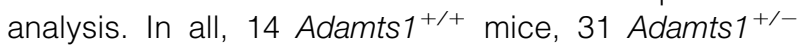
mice (randomly chosen), and 21 Adamts $1^{-1-}$ mice were used in the histological analysis of primary and metastatic tumors. 


\section{Mammary Whole-Mount Preparations and Tumor Histology}

Fourth abdominal mammary glands from Adamts $1^{+/+}$ and Adamts $1^{-1-}$ mice at 6 and 12 weeks of age were dissected. Whole mounts were fixed in Carnoy's fixative and stained in carmine stain and imaged using a Nanozoomer scanner with NDP View software version 2.0 (Hamamatsu Photonics, Hamamatsu City, Japan). From these images, the average number of branch points was determined per millimeter for each of three primary ducts per gland and statistical analysis compared the number of branch points for Adamts $1^{+/-}(n=6)$ versus $A d$ amts $1^{-1-}$ mice $(n=7)$. For histological assessment, $5-\mu \mathrm{m}$ sections from paraffin blocks from the either the left or right fourth abdominal mammary gland were stained with H\&E and imaged on the Nanozoomer. Tumors from PyMT $^{+}$Adamts ${ }^{+/+}(n=15)$, and Adamts $1^{-/-}(n=21)$ mice between 16 and 20 weeks of age were examined in a blinded setting by an experienced pathologist (K.O.) and were categorized as ductal carcinoma in situ (DCIS), well differentiated invasive ductal carcinoma (grade 1), moderately differentiated ductal carcinoma (grade II), or poorly differentiated ductal carcinoma (grade III).

\section{Assessment of Lung and Lymph Node Metastasis}

Sections of lung tissue (5 $\mu \mathrm{m})$ were stained with $H \& E$, and 30 random images at $\times 10$ magnification were captured by an operator blinded to genotype at tissue depths $100 \mu \mathrm{m}$ apart, using a video image analysis system (VideoPro 32 version 2.1; Leading Edge, Marion, Australia). The number of lung metastases per 30 captured fields was counted, and percentage total area occupied by metastases was measured (in pixels) using AnalySIS digital image analysis software Olympus (AnalySIS LS Professional version 5.0; Olympus). Lymph node assessment at four depths separated by $100 \mu \mathrm{m}$ was performed in tissue stained with H\&E and immunostained for Her2/ neu (1:500, A0485; Dako Australia, Campbellfield, Australia), which is overexpressed by PyMT tumors, using a method described previously. ${ }^{29}$

\section{Immunohistochemistry}

Tumor sections were mounted on positively charged slides (SuperFrost Plus; Menzel-Glaser, Braunschweig, Germany) and heated at $60^{\circ} \mathrm{C}$ for 1.5 hours. After dewaxing of sections in xylene and after rinsing in ethanol and $\mathrm{PBS}$, endogenous peroxidase activity was quenched in $0.3 \% \mathrm{H}_{2} \mathrm{O}_{2}$. For immunostaining of ADAMTS1 (rabbit polyclonal, 1:200, H-60; Santa Cruz Biotechnology, Santa Cruz, CA), active caspase-3 (rabbit polyclonal, 1:200; Cell Signaling Technology, Danvers, MA), Ki-67 (rabbit monoclonal, 1:400; Epitomics, Burlingame, CA), $\alpha$ smooth muscle actin ( $\alpha$-SMA rabbit polyclonal, 1:200, Ab5694; Abcam, Cambridge, UK), CD34 (rat monoclonal, 1:50, clone MEC 14.7; Abcam), CD45 (rat monoclonal clone IBL-3/16, 1:200; AbD Serotec, Morphosys UK,
Oxford, UK), CD3 (rat monoclonal clone IBL-3/16, 1/800; BD Biosciences, Sydney, Australia), F480 (rat monoclonal clone Cl:A3-1, 1:200; AbD Serotec, Morphosys UK), and IL-12 (rat monoclonal clone C15.6, 1:100; eBioscience, San Diego, CA), target antigens were unmasked in boiling 0.1 $\mathrm{mol} / \mathrm{L}$ citrate $\mathrm{pH} 6.0$ buffer. Sections for versican immunostaining [rabbit anti-mouse, 1:500, GAG $\beta$ domain (Millipore, Sydney, Australia) or rabbit polyclonal, 1:200, antiDPEAAE (Thermo Fisher Scientific, Rockford, IL)] were pretreated with chondroitinase ABC $(0.1 \mathrm{U} / \mathrm{mL}$; Seikagaku, Tokyo, Japan) at $\mathrm{pH} 8$ for 90 minutes, which removes chondroitin sulfate side chains as well as having residual activity against hyaluronan $(\mathrm{HA}) .^{30}$

For detecting lymphatic vessels (anti-Lyve1, 1:500; Millipore), tissues were incubated with proteinase $\mathrm{K}$ buffer (1 $\mu \mathrm{g} / \mathrm{mL}$, Sigma-Aldrich, Sydney, Australia) for 20 minutes. To eliminate nonspecific binding, tissues were blocked in 5\% goat or rabbit serum (Sigma-Aldrich, St. Louis, MO) for 20 minutes or 1 hour (Lyve1), and then were incubated overnight at $4^{\circ} \mathrm{C}$ with primary antibody. Washed sections were subsequently incubated with biotinylated goat anti-rabbit (1:400; Dako Australia) or rabbit anti-rat IgG (1:400; Australian Laboratory Services, Stafford, Australia) for 1 hour at room temperature followed by incubation for 1 hour with streptavidin-horseradish peroxidase conjugate (1:500; Dako). Positive immunoreactivity was detected using diaminobenzidine substrate and $10 \%$ hematoxylin counterstain. HA was detected using biotinylated HA binding protein (HABP; 1:250; NorthStar Bioproducts, Associates of Cape Cod, East Falmouth, MA). as described previously. ${ }^{31}$ Sections were then dehydrated and mounted in Pertex mounting medium (HD Scientific, Glengala, Australia). Each tissue had a matching negative control lacking the primary antibody incubation step.

\section{Morphometric Measurement of Immunostained Tissues}

The ADAMTS1 staining level in tumors derived from the fourth mammary glands of $\mathrm{PyMT}^{+} /$Adamts $1^{+/+}$mice at 9 weeks $(n=5), 12$ to 14 weeks $(n=7)$, and 16 to 20 weeks $(n=8)$ was measured by video image analysis (VideoPro 32; Leading Edge), as previously described. ${ }^{20}$ Staining intensity was expressed as mean integrated optical density units (MIOD) per tumor area. For Ki-67, cleaved caspase 3, CD34, versican, HA, $\alpha$-SMA, CD45, $\mathrm{F} 480$, and CD3, stained tissues were scanned using the Nanozoomer. Five random images of each tissue were captured at $\times 20$ magnification using NDP View (Hamamatsu) imaging software. Color threshold detection by AnalySIS-Pro software (Olympus) was used to determine positive (brown pixels) and negative (purple pixels) stained cells per tumor area. Normal glands, DCIS lesions, and any artifacts present in the images were masked and excluded from analysis. Data are expressed as percentage of positive cells (positive brown stained divided by negative purple stained area) for cellular stains (Ki-67 and activated caspase-3). Extracellular stains (CD34, versican, HA, $\alpha$-SMA, CD45, F480, and 
CD3) were expressed as percent positive area over total area analyzed. Because of lower abundance of $\mathrm{IL}-12^{+}$ cells in the tumor tissues, IL-12 positivity was assessed visually in 10 high power fields (captured at $\times 40$ magnification) by two independent observers (C.R. and K.M.F.). The genotype of the mouse tumors was blinded until completion of all analyses.

\section{Versican RT-PCR and Quantitative RT-PCR}

Total RNA was isolated from $\mathrm{PyMT}^{+} \mid$Adamts $1^{+/+}(n=5)$ and $\mathrm{PyMT}^{+} /$Adamts $^{-1-}(n=5)$ tumor tissue, and RTPCR for versican isoforms was performed as described previously. ${ }^{30}$ For real-time quantitative PCR, cDNA was synthesized using random primers and SuperScript III reverse transcriptase (Invitrogen, Carlsbad, CA), according to the manufacturer's instructions. Versican primers and PCR conditions were as described previously. ${ }^{32}$ Samples were calibrated using the housekeeping gene L19 (QuantiTect primer assays; Qiagen, Hilden, Germany) using the $2^{-\Delta \Delta C T}$ method.

TaqMan low-density array (TLDA) assay of 92 immune related and 4 internal genes was performed using $1 \mu \mathrm{g}$ cDNA in $100 \mu \mathrm{L}$ of $1 \times$ universal PCR master mix (Applied Biosystems, Foster City, CA) loaded onto each port of the TLDA plates. Thermocycling was performed on an $A B I$ Prism 7900HT sequence detection system (Applied Biosystems), according to the manufacturer's instructions. Tumor RNA extracts from four individual mice of each genotype were used. Data were analyzed using SDS version 2.2 sequence detection software (Applied Biosystems). The $C_{t}$ values were normalized to $18 \mathrm{~S}$, and relative quantitation of gene expression was determined using the $2^{-\Delta \Delta \mathrm{CT}}$ formula with an Adamts $1^{+/+}$RNA sample as the calibrator. Data are presented as the fold change difference in Adamts $1^{-/-}$versus Adamts $1^{+/+}$ samples.

\section{Versican Western Blot Analysis}

Tumor tissue from PyMT ${ }^{+} /$Adamts $1^{+/+}(n=5)$ and PyMT $^{+} /$Adamts $^{-1-}(n=5)$ was extracted in buffer containing $0.1 \%$ Triton $\mathrm{X}-100$ surfactant, $6 \mathrm{~mol} / \mathrm{L}$ urea, and protease inhibitors, and extracts were treated with chondroitinase $\mathrm{ABC}$, as described previously. ${ }^{30}$ Western blots on $10 \mu \mathrm{g}$ of tissue extract used rabbit anti-mouse versican antibody against the GAG $\beta$ domain (1:1000; Millipore) and $\beta$-actin antibody (Millipore) as a loading control. Visualization was achieved using anti-rabbit IgG peroxidase-conjugated secondary antibody (1/10,000; Bio-Rad Laboratories, Hercules, CA) with enhanced chemiluminescence (Amersham; GE Healthcare, Little Chalfont, UK). Intensity of versican bands were measured using ImageQuant software version 5.0 (Molecular Dynamics, Melbourne, Australia) and normalized to $\beta$-actin levels.

\section{Statistical Analysis}

All statistical analyses were performed using SPSS software, version 15.0 for Windows (SPSS, Chicago, IL). The Mann-Whitney U-test, Kruskal-Wallis tests, or $\chi^{2}$ analysis was used to determine statistical significance between the different genotype groups. Spearman's rank correlation test was used to determine the correlations of tumor size and lung metastasis between levels of ADAMTS, versican, or vascular density. Kaplan-Meier survival analyses were performed to determine differences in survival with time to reach tumor burden $\geq 3 \mathrm{~cm}^{3}$ in the three mouse genotypes. For gene expression experiments, statistical significance was determined by two-tailed $t$ tests. Statistical significance was accepted at $P<0.05$.

\section{Results}

\section{ADAMTS1 Is Present in Tumor Cells and Is Increased with Tumor Development}

ADAMTS1 immunostaining was low or undetectable in normal mouse mammary tissue (data not shown). In $\mathrm{PyMT}^{+} /$Adamts $^{+/ /+}$mice at 9 weeks of age, DCIS lesions contained elevated levels of ADAMTS1, compared with normal mammary glands (Figure 1A). ADAMTS1 was more intensely stained in the epithelial cells of invasive carcinoma lesions developed between 16 and 20 weeks of age, but very low levels of ADAMTS1 were detected in the peritumoral stroma (Figure 1A). Confirming the antibody specificity, no immunoreactivity was observed in the absence of primary antibody or in $\mathrm{PyMT}^{+} /$ Adamts $1^{-1-}$ tumors at 20 weeks of age (Figure 1A). Quantitative analysis showed significantly increased protein abundance in Adamts $1^{+/+}$tumors at 16 to 20 weeks of age, compared with tumors at 9 weeks and at 12 to 14 weeks of age (Figure 1B). The level of ADAMTS1 was also significantly correlated with tumor weight in Adamts $1^{+/+}$ mice $(\rho=0.587, P=0.008$; Figure $1 C)$.
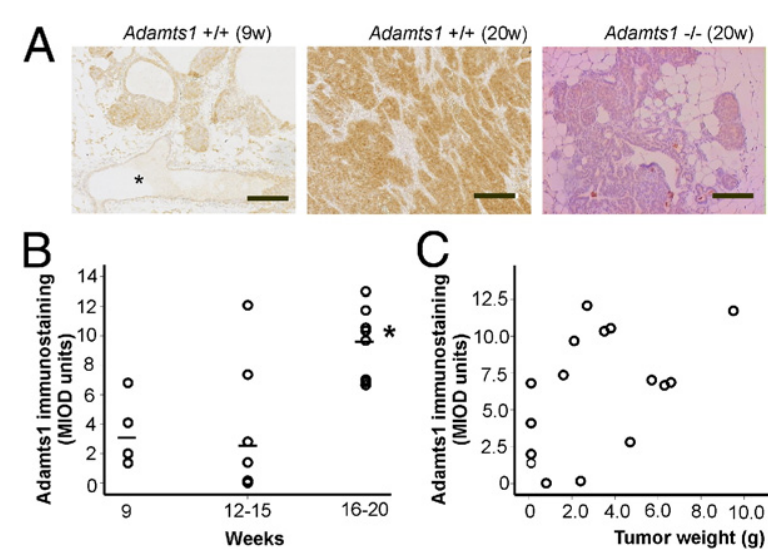

C

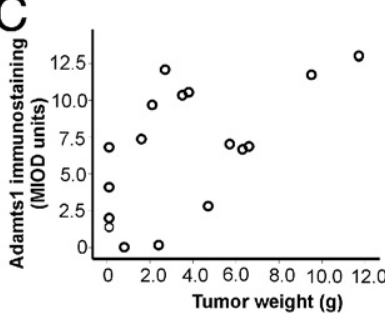

Figure 1. ADAMTS1 is present in tumors and increases with tumor progression. A: ADAMTS1 immunostaining in Adamts $^{+/ /+} /$PyMT tumors in mice at 9 weeks $(9 \mathrm{w})$ and at 20 weeks (20w) of age. The specificity of the antibody was confirmed by lack of staining in Adamts $^{-/-} /$PyMT tumor at 20 weeks of age. Asterisk indicates normal glands. Scale bar $=100 \mu \mathrm{m}$. B: Relative abundance of ADAMTS1 in tumors at early ( 9 weeks), mid (12 to 15 weeks), and late (16 to 20 weeks) stage quantitated by Video-Pro image analysis. ADAMTS1 immunostaining was significantly elevated in Adamts $1^{+/} /$PyMT tumors at 16 to 20 weeks of age, compared with earlier time points. ${ }^{*} P=$ 0.024, Kruskal-Wallis test. C: ADAMTS1 immunostaining was significantly correlated with total tumor weight (Spearman's $\rho=0.587, P=0.008$ ). 
Table 1. Incidence of Tumor Development and Lung and Lymph Metastasis in Adamts1-PyMT Mouse Cohorts

\begin{tabular}{|c|c|c|c|c|c|c|}
\hline \multirow[b]{2}{*}{ Genotype } & \multicolumn{2}{|c|}{$\begin{array}{c}\text { Palpable tumor development } \\
(\%)\end{array}$} & \multicolumn{2}{|c|}{$\begin{array}{l}\text { Lung metastasis at } 16 \text { to } \\
20 \text { weeks (\%) }\end{array}$} & \multicolumn{2}{|c|}{$\begin{array}{c}\text { Lymph node metastasis at } 16 \text { to } \\
20 \text { weeks (\%) }\end{array}$} \\
\hline & No & Yes & No & Yes & No & Yes \\
\hline Adamts $1^{+/+}$ & $0 / 14(0)$ & $14 / 14(100)$ & $3 / 14(21.4)$ & $11 / 14(78.8)$ & $8 / 10(80.0)$ & $2 / 10(205.0)$ \\
\hline Adamts $1^{+/-}$ & $4 / 48(8.3)$ & $44 / 48(91.7)$ & $9 / 31(29.0)$ & $22 / 31(71.0)$ & $17 / 18(94.4)$ & $1 / 18(5.6)$ \\
\hline Adamts 1-1- & $5 / 21(23.8)$ & $16 / 21(76.2)$ & $13 / 21(61.9)$ & $8 / 21(38.1)$ & $17 / 17(100)$ & $0 / 17(0)$ \\
\hline Pearson's $\chi^{2}$ & \multicolumn{2}{|c|}{$P=0.072$} & \multicolumn{2}{|c|}{$P=0.02$} & \multicolumn{2}{|c|}{$P=0.128$} \\
\hline
\end{tabular}

\section{Adamts $1^{-/-}$Mice Have Delayed Tumor Development, Reduced Tumor Burden, and Increased Survival}

Mammary tumors were first detected between 10 and 20 weeks of age; the wide variation is possibly a result of the mixed strain background. The incidence of palpable tumor development was not statistically different among the three genotypes (Table 1). The age at first identification of palpable tumors was not significantly different in $\mathrm{Ad}$ amts $1^{-1-}$ (median, 16.4 weeks; range, 10.3-20 weeks) mice, compared with Adamts $1^{+/-}$(median, 14.6 weeks; range, 11.3-19.4) or Adamts $1^{+/+} /$PyMT mice (median, 14.3 weeks; range, $10.1-17.3)(P=0.07$, Kruskal-Wallis test) (Figure 2A). Tumor burden in the mammary glands, after euthanasia, was dramatically reduced in Adamts $1^{-1-}$ mice, compared with Adamts ${ }^{+/-}$or Adamts $1^{+/+} /$PyMT mice $(P<0.0001$, Kruskal-Wallis test; Figure 2B). The reduced tumor burden was not associated with perturbed mammary gland development in Adamts $1^{-\prime-}$ mice; normal ductal length at 6 weeks of age (data not shown) and normal ductal branch numbers at 12 weeks were observed in Adamts $1^{-1-}$ mice, compared with Adamts $1^{+/-}$mice (see Supplemental Figure S1, A and $\mathrm{B}$, at $h$ ttp://ajp.amjpathol.org). The growth of tumors until the time of ethical euthanasia was analyzed by KaplanMeier survival plot, comparing the rate of euthanasia based on tumor burden reaching $>3 \mathrm{~cm}^{3}$ in the three genotypes. Adamts $1^{+/+}$mice displayed a greater occurrence (12/14, $85.7 \%$ ) of euthanasia due to a large tumor burden, compared with heterozygous mice $(17 / 31,54.8 \%)$ and particularly knockout mice $(5 / 21,23.8 \%)(P<0.001$; Figure $2 \mathrm{C})$. Adamts $1^{-1-}$ mice had a reduced incidence of early euthanasia due to large tumor burden, and more often survived up to the experimental endpoint of 20 weeks (Figure 2C).

\section{Histopathology of Adamts $1^{+/+}$and Adamts $1^{-/-}$/PyMT Tumors}

The fourth abdominal mammary gland tumors were classified histopathologically as DCIS, grade II, and grade III (see Supplemental Figure S1C at http://ajp.amjpathol. org). No PyMT tumors of grade I were observed. The Adamts $1^{-1-}$ mice had a significantly increased proportion of tumors with exclusively DCIS lesions and no invasive tumor (5/21; $P=0.007$, Pearson's $\chi^{2}$ test) (Figure $2 \mathrm{D})$. Furthermore, a significantly greater proportion of Adamts $1^{+/+}$mice had grade III invasive tumors (11/15), compared with Adamts $1^{-1-}$ mice (5/21) (Figure 2D).

\section{Adamts $1^{-1-}$ Mice Have Reduced Metastasis}

Metastases to lymph nodes were rarely identified. Examination of lymph nodes reported to be draining lymph nodes for mouse mammary glands (ie, the axillary and brachial lymph nodes) revealed metastases in the axillary lymph node in 2/10 Adamts $1^{+/+}$mice and $1 / 18$ Adamts $1^{+/-}$mice (Table 1; see also Supplemental Figure
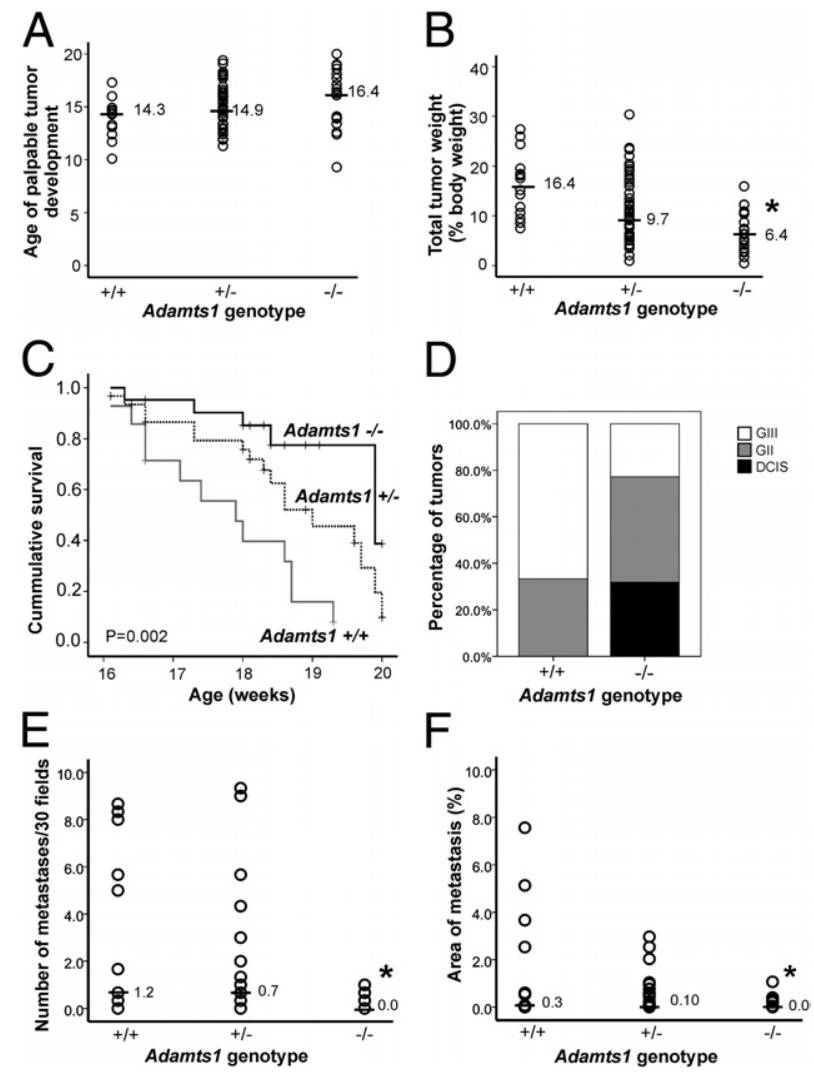

Figure 2. Tumor progression is reduced in Adamts $1^{-/} / \mathrm{PyMT}$ mice. ADAMTS1-deficient mice develop tumors at similar age to controls, but showed reduced primary mammary tumor burden, increased survival to ethically mandated euthanasia and lower histopathological grade and pulmonary metastasis. A: Age of first palpable tumor observation. $P=0.071$, Kruskal-Wallis test. B:

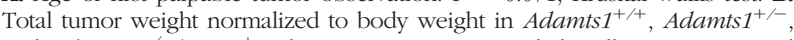
and Adamts $1^{-/} / \mathrm{PyMT}^{+}$cohorts. ${ }^{*} P<0.0001$, Kruskal-Wallis test. Horizontal lines indicate the median for each cohort (A and B). C: Survival to ethically mandated euthanasia in Adamts1/PyMT ${ }^{+}$mice cohorts (Mantel-Cox log-rank test statistic $13.58, P=0.001)$. D: Proportion of DCIS, grade II (GII), and grade III (GIII) invasive tumors in Adamts $1^{+/+}(n=15)$ and Adamts ${ }^{-/-} / \mathrm{PyMT}^{+}$ mice $(n=21)$. E: Number of lung metastases identified in 30 random fields from serial sections spanning lung tissue at $100-\mu \mathrm{m}$ increments in Adamts1/PyMT mouse cohorts. ${ }^{*} P=0.016$, Kruskal-Wallis test. F: Percentage of lung area containing metastases in serial sections spanning the tissue at $100-\mu \mathrm{m}$ increments of Adamts1/PyMT mice cohorts. ${ }^{*} P=0.028$, Kruskal-Wallis test. 


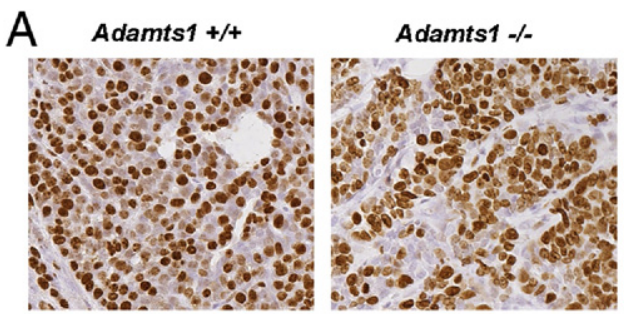

B Adamts1 +/+

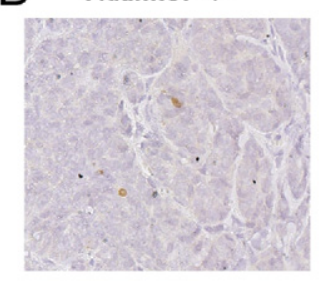

C

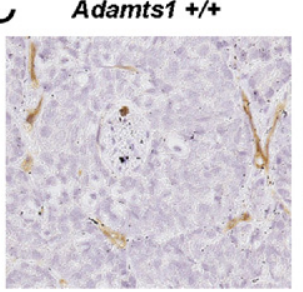

Adamts1 -/-

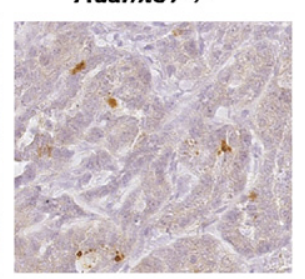

Adamts1 \%

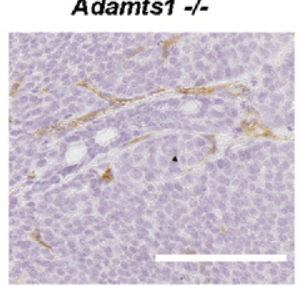

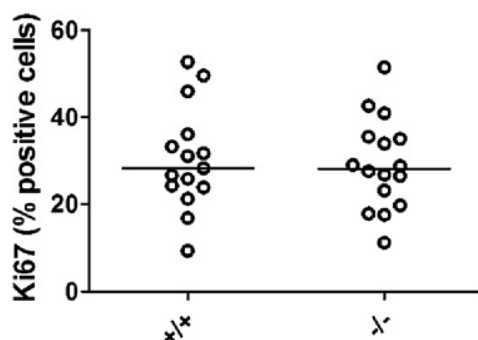
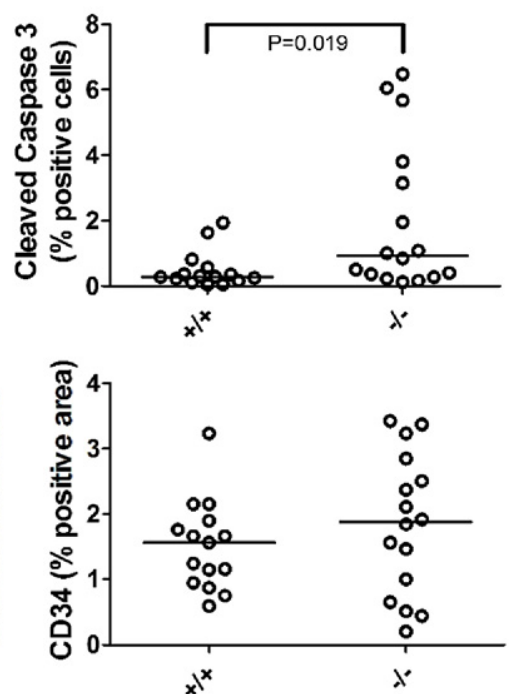

Figure 3. Apoptosis in tumor cells is increased but proliferation and blood vasculature are equivalent in Adamts $1^{-/} /$PyMT tumors. Proliferative index, apoptotic index, and blood vesse density were assessed by image analysis of immunostained tumor sections of Adamts $1^{+/+}$ $(n=15)$ and Adamts1 ${ }^{-/} /$PyMT $(n=16)$ tumors. Representative examples of immunolabeling are shown for Ki-67 (A), cleaved caspase 3 (B), and $\mathrm{CD}_{4}$ (C) in Adamts $1^{+/+}$and Adamts $1^{-1}$ mice, with quantitated levels. A: The proportion of $\mathrm{Ki}-67^{+}$proliferating cells was not significantly different between genotypes. $P=0.922$, Mann-Whitney U-test. B: Cleaved caspase $3^{+}$apoptotic cell numbers were increased in Adamts $1^{-/-} /$PyMT tumors. ${ }^{*} P=$ 0.019 , Mann-Whitney U-test. C: Blood vessel density measured by area of CD34 immunostaining was not significantly different before genotypes. $P=0.423$, Mann-Whitney $U$-test. Scale bar $=100 \mu \mathrm{m}$; all images are at the same original magnification.
S2, A and B, at http://ajp.amjpathol.org). The lower incidence of axillary lymph node metastasis in Adamts ${ }^{-1-}$ mice did not reach statistical significance $\left(P=0.128, \chi^{2}\right.$ test) (Table 1). No metastasis was seen in the brachial lymph node of mice of any genotypes.

The incidence of lung metastases quantified systematically by serial sectioning and morphometric measurement of lungs (see Supplemental Figure S2, B and C, at http://ajp.amjpathol.org) was significantly higher in Adamts $1^{+/+}$mice, compared with Adamts $1^{-1-}$ littermates, with heterozygous mice showing an intermediate metastatic incidence (Table 1). The number of metastatic lesions (Figure 2E) and the percent lung area occupied by metastases (Figure 2F) were significantly lower in the Adamts $1^{-1-}$ mice, compared with the Adamts $1^{+/-}$or Adamts ${ }^{+/+}$littermates (number of lesions, $P=0.016$; area occupied, $P=0.028$, Kruskal-Wallis test). The number and area of lung metastases in Adamts $1^{+/+}$mice were not correlated with primary mammary tumor burden [Spearman's $\rho=0.363(P=0.264)$ and $\rho=0.303(P=$ 0.194), respectively].

\section{Apoptotic Rate Increases but Proliferation and Blood Vessel Density Do Not Increase in Adamts $1^{-1-}$ /PyMT Tumors}

The proliferative index measured by Ki-67 immunopositivity in the fourth abdominal mammary gland tumors was not statistically different between Adamts $1^{+/+}$and Adamts $1^{-1-}$ tumors ( $P=0.922$, Mann-Whitney $U$-test;
Figure 3A). However, the apoptotic index, determined by cleaved caspase-3 immunostaining, was significantly increased in Adamts $1^{-/-}$tumors $(P=0.024$, Mann-Whitney $U$-test; Figure 3B).

The tumor vasculature provides nutrients and gas exchange, which indirectly support cell survival, proliferation, and tumor growth, as well as providing a portal for cancer cell dissemination to secondary metastatic sites. $\mathrm{CD}_{4}{ }^{+}$blood vessel density was not statistically different between Adamts $1^{+/+}$and Adamts $1^{-/-}$tumors $(P=$ 0.423, Mann-Whitney U-test; Figure 3C). Furthermore, vascular density was not correlated with tumor size in either the Adamts ${ }^{+/+}$(Spearman's $\rho=0.105, P=$ 0.746) or the Adamts $1^{-/-}$tumor cohorts (Spearman's $\rho=$ $-0.211, P=0.450)$.

Because ADAMTS1 regulates lymphangiogenesis during ovarian follicle development, ${ }^{3}$ we measured lymphatic vessel density by Lyve1 immunostaining. Our assessments showed lymphatic vessels only beyond the tumor periphery in both Adamts $1^{+/+}$and Adamts $1^{-/-}$ tumors (see Supplemental Figure S2E at http://ajp. amjpathol.org). Because intratumoral lymphatic vessels were rare, no further quantitation of lymphatic vasculature was performed.

\section{ADAMTS1 Expression Leads to the Accumulation of Versican in Peritumoral Stroma}

Breast and prostate tumors are known to remodel the peritumoral stroma, inducing a reactive phenotype that 
A
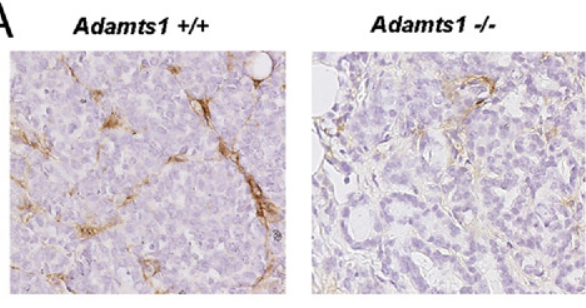

B
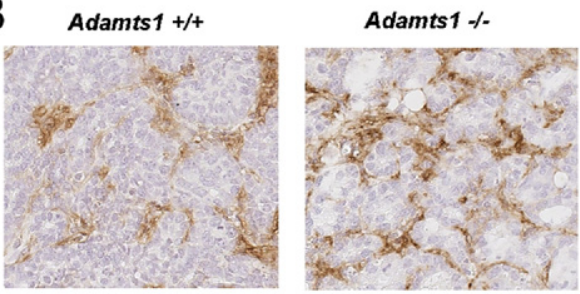

C
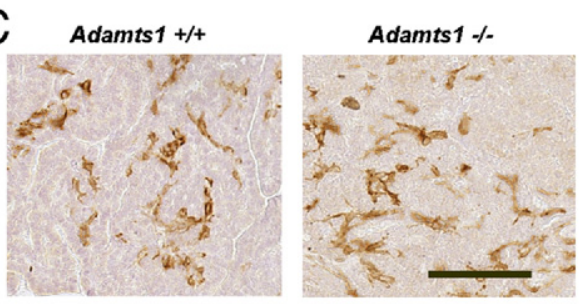
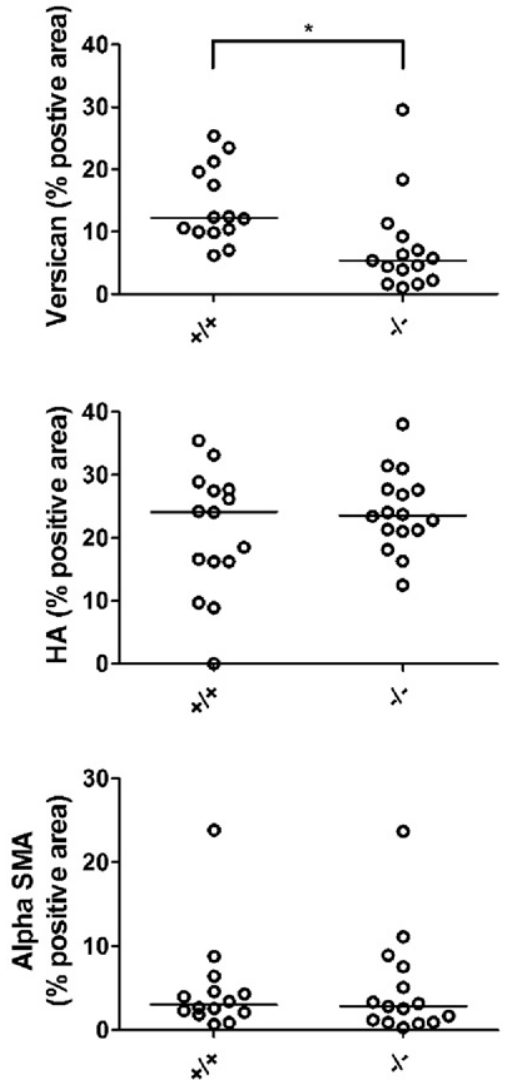

Figure 4. ADAMTS1 enhanced stromal versican accumulation, without altering total stromal volume. Versican, hyaluronan (HA), and $\alpha$-smooth muscle actin ( $\alpha$-SMA) immunostaining or HAbinding protein (HABP) affinity labeling of tumor sections of fourth mammary gland containing invasive tumors from Adamts $1^{+/+}(n=15)$ and Adamts $1^{-1-}$ PyMT $(n=16)$ mice. Representative examples of immunolabeling are shown for versican (A), HA (B), and $\alpha$-SMA (C) in Adamts $^{+/+}$and Adamts $1^{-/-}$mice, with quantitated levels. A: Versican immunostaining area was significantly lower in Adamts $1^{-1}$, PyMT tumors. ${ }^{*} P=0.001$, Mann-Whitney $U$-test B: HA levels were not significantly different between genotypes. $P=0.792$, Mann-Whitney $U$-test. C: $\alpha$-SMA levels were not significantly different between genotypes. $P=0.792$, MannWhitney $U$-test. Scale bar $=100 \mu \mathrm{m}$; all images are at the same magnification. promotes tumor progression. ${ }^{33}$ We investigated whether ADAMTS1 affects stromal remodeling by measuring levels of versican, $\mathrm{HA}$, and $\alpha$-SMA in the tumor cohorts. Immunostaining using an antibody that detects both intact and cleaved versican showed positive staining in peritumoral stroma, which was significantly elevated in Adamts $1^{+/+}$tumors, compared with Adamts $1^{-/-}$tumors $(P=0.001$, Mann-Whitney $U$-test; Figure 4A). Versican staining levels in Adamts $1^{+/+}$and Adamts $1^{-/-}$tumors significantly correlated with tumor size (Spearman's $\rho=0.385, P=0.039$ ) and metastatic burden (Spearman's $\rho=0.378, P=0.048$ ). Of note, metastases in the lungs of Adamts $1^{+/+}$mice also showed stromal versican staining, despite low versican abundance in the normal lung (see Supplemental Figure S2D at http://ajp.amjpathol. org), suggesting that tumors producing ADAMTS1 had increased immunodetection of versican in both mammary and lung stromal environments. The higher versican staining in the Adamts $1^{+/+}$mammary tumors was not a result of increased stromal volume, because levels of HA, a stromal marker and known mediator of tumor progres$\operatorname{sion}^{34}(P=0.520$, Mann-Whitney $U$-test; Figure 4B) and of $\alpha$-SMA, a marker of infiltrating myofibroblasts, ${ }^{35}$ were abundant in peritumoral stroma but were not different between the two genotypes ( $P=0.712$, Mann-Whitney U-test; Figure 4C). Isoform-specific RT-PCR analysis demonstrated that $\mathrm{V} 0$ and $\mathrm{V} 1$ versican were abundant, and that low levels of V2 and V3 versican isoforms were present in both Adamts $1^{+/+}$and Adamts $1^{-/-}$tumors (Figure 5A). Real-time quantitative PCR revealed that total versican mRNA levels were not different between Adamts $1^{+/+}$and Adamts1 ${ }^{-/-}$tumors $(P=0.841$, Mann-Whitney $U$-test; Figure 5B). Western blotting with the anti- $\beta$-GAG antibody showed that the $70-\mathrm{kDa}$ cleaved versican $V_{1}$ was significantly elevated in Adamts $1^{+/+}$, compared with Adamts $1^{-/-}$tumors $(P=$ 0.029, Mann-Whitney U-test; Figure 5, C and D). The identity of the $\beta$-GAG-positive versican band at $75 \mathrm{kDa}$, most abundant in the Adamts1-/- tumor extract, is unknown. A single band of $>500 \mathrm{kDa}$ appears to be intact versican, which was equally abundant in extracts of both Adamts $1^{+/+}$and Adamts $1^{-/-}$tumors. The anti$\beta$-GAG versican antibody detected abundant intact and cleaved versican in mouse COC extract as described previously. ${ }^{4}$ The $70-\mathrm{kDa}$ cleaved versican $\mathrm{V} 1$, which was more abundant in Adamts $1^{+/+}$, compared with Adamts $1^{-1-}$ tumors, was shown to represent the ADAMTS1-cleaved form with an antibody to the DPEAAE neo-epitope (Figure 5E). The high reactivity with this antibody only in wild-type tumors suggests that cleavage of versican in these tumors is due primarily to ADAMTS1. Further support for this idea was obtained from immunohistochemistry, which showed strong DPEAAE neo-epitope staining in stroma of Adamts $1^{+/+}$but not in Adamts $1^{-/-}$tumor sections (Figure $5, F$ and $G$ ). This concentration of cleaved versican in breast cancer stroma suggests that active ADAMTS1 produced by tumor cells diffuses to this site, where it cleaves versican. 


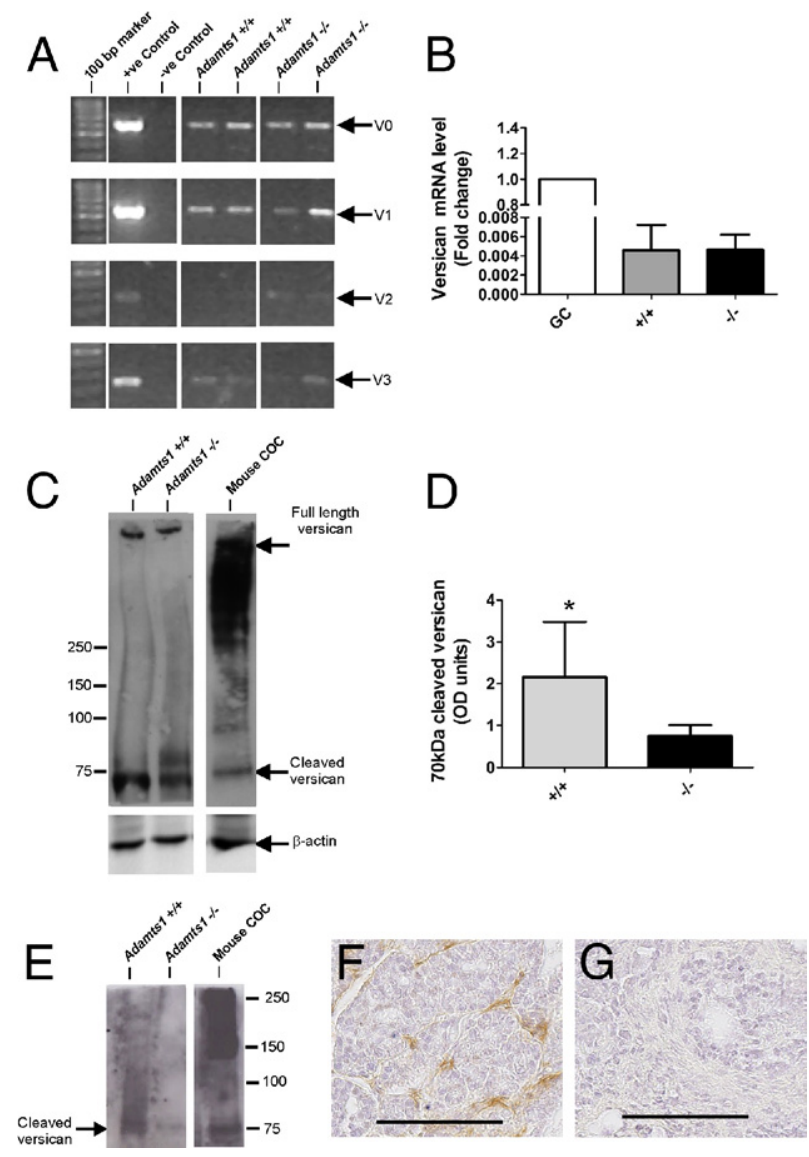

Figure 5. Versican mRNA expression is equivalent, but cleaved versican protein is reduced, in Adamts $1^{-/-} /$PyMT versus Adamts $1^{+/+} /$PyMT tumors. A: RT-PCR of versican isoforms in Adamts $1^{+/+} /$PyMT and Adamts $1^{-1-}$, PyMT tumors. B: qRT-PCR for total versican in Adamts $1^{+/+} /$PyMT $(n=5)$ and Adamts $1^{-/} /$PyMT tumor RNA $(n=5)$ calibrated against versican collected from granulosa cell (GC) extracts. C: Western blot of equal amounts of protein from tumor lysates of Adamts $1^{+/+} / \operatorname{PyMT}(n=4)$ and Adamts $1^{-/-}$ PyMT tumors $(n=4)$ were analyzed by using versican and $\beta$-actin antibodies. An extract of cumulus oocyte complexes (COC) from ovaries stimulated with human chorionic gonadotropin for 12 hours to induce ovulation was included as a positive control, indicating the known size properties of intact and ADAMTS1-cleaved versican isoform V1. D: Intensity of versican bands was measured using ImageQuant software (Molecular Dynamics; Melbourne Australia) and normalized to $\beta$-actin levels. Data are expressed as means \pm SD ${ }^{*} P=0.029$, Mann-Whitney $U$-test. E: Adamts $1^{+/+} /$PyMT and Adamts $1^{-/} /$PyMT tumor lysate and COC extract immunoblotted with neo-epitope versican antibody to ADAMTS cleavage site (anti-DPEAAE). F and G: Immunohistochemistry with anti-DPEAAE versican antibody revealed cleaved versican in Adamts $^{+/+}$, PyMT tumor tissues $(\mathbf{F})$, but not in $\operatorname{Adamts}^{-/-} /$PyMT $(\mathbf{G})$ tumor tissues. Scale bars $=100 \mu \mathrm{m}$.

\section{Increased CD45 Leukocytes and Th1 Immune} Gene Expression in Adamts $1^{-1-} /$ PyMT Tumors

Additional characterization of the peritumoral stroma in the PyMT tumors revealed increased density of $\mathrm{CD} 45^{+}$

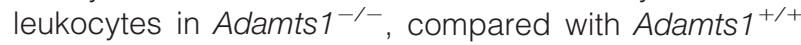
tumors (Figure 6A). Further analysis with specific immune cell markers revealed no difference in macrophage cell density (F480; Figure 6B) or T-lymphocyte cell density (CD3; Figure 6C). We used a qPCR TLDA of immunerelated genes to further explore changes in immune cell types in extracts of Adamts $1^{+/+}$and Adamts $1^{-/-}$tumors. Out of six genes showing greater than twofold increase in Adamts $1^{-1-}$ versus Adamts $1^{+/+}$tumors, five were cyto-

toxic cell markers CD4OL (IL-12a, SOCS2, Tbx21t, and granzyme B; see Supplemental Table S1 at http://ajp. amjpathol.org). This finding was supported by the demonstration of significantly elevated $\mathrm{IL}-12^{+}$cell numbers in Adamts $1^{-1-}$ tumor tissue sections, compared with $\mathrm{Ad}$ amts $1^{+/+}$tumors (Figure 6D). Of four genes down-regulated by twofold or more, three were Th2 markers [CCR4, CSF3 (alias GCSF), and PTGS2; see Supplemental Table S2 at http://ajp.amjpathol.org]. Taken together, these results suggest a switch toward a Th1-type immune response in ADAMTS1-deficient tumors.

\section{Discussion}

Proteases play important roles in tissue remodeling and modulating cell microenvironments through degradation of the ECM and processing of growth factors and adhesion molecules. To metastasize, tumor cells must acquire the capacity to invade through the peritumoral ECM barrier, and reactive tumor-stroma interactions also play a role in cancer progression, promoting cell proliferation, motility, and invasion. ${ }^{36}$ Metastasis requires that cells detach from the primary tumor mass, invade the surrounding ECM, enter the vasculature, and then extravasate and grow at distant sites, ${ }^{37}$ with each step necessitating cellular proteases that remodel the ECM environment. Our results indicate that ADAMTS1 becomes up-regulated in advanced-stage PyMT tumors and participates in the remodeling of the peritumoral stroma, tumor growth, and pulmonary metastasis. Specifically, tumor cell survival, cleavage of versican, and a tolerogenic immune cell phenotype in the peritumoral stroma were promoted by ADAMTS1.

The incidence of mammary tumors and of pulmonary metastasis was not affected in Adamts $1^{-1-}$ MMTV-PyMT transgenic mice, but the growth of mammary tumors and

\section{A}
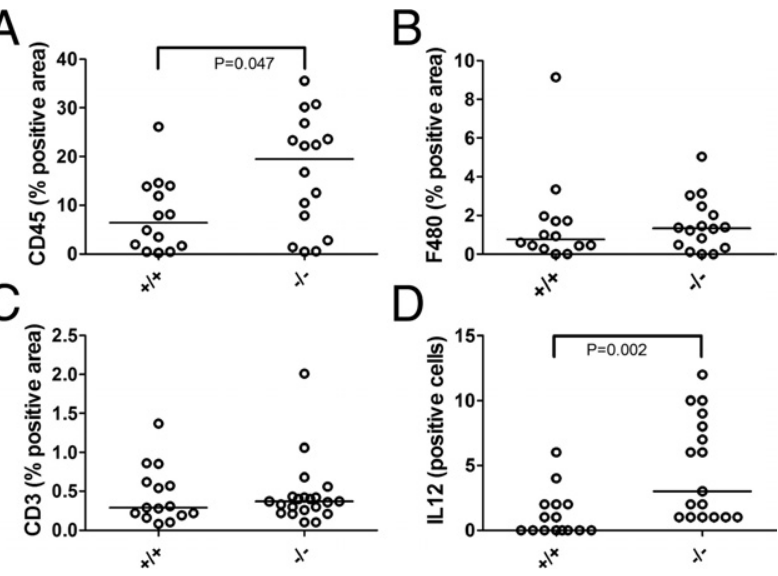

Figure 6. Numbers of $\mathrm{CD} 45^{+}$leukocytes and IL- $12^{+}$cells are increased in Adamts $1^{-1} /$ PyMT tumors. A: Leukocyte numbers measured by CD 45 positivity were increased in Adamts $1^{-/-}$PyMT tumors. $P=0.047$, Mann-Whitney $U$-test. B: Macrophage numbers measured by F480 positivity were not significantly different between Adamts $1^{+/+} / \mathrm{PyMT}_{\mathrm{P}}$ and Adamts $1^{-/} / \mathrm{PyMT}$ tumors. $P=0.714$, Mann-Whitney $U$-test. C: T-lymphocyte numbers measured by $\mathrm{CD} 3$ positivity were not significantly different between $A d a m t s 1^{+/+} / \mathrm{PyMT} A d-$ amts $1^{-1-}$ PyMT tumors. $P=0.790$, Mann-Whitney $U$-test. $\mathbf{D}$ : The number of IL- $12^{+}$cells (10 fields at $\times 40$ magnification) was increased in Adamts $1^{-/} /$PyMT tumors, relative to Adamts $1^{+/+} /$PyMT tumors. $P=0.002$, Mann-Whitney $U$-test. 
metastases were reduced. Our present findings show that mammary gland development is not altered, and previously we have reported normal ovarian steroid levels in Adamts $1^{-1-}$ mice. ${ }^{3,31}$ More aggressive tumor behavior was associated with the capacity to express high levels of ADAMTS1. In PyMT ${ }^{+} /$Adamts $1^{+/+}$tumors, the level of ADAMTS1 increased with advancing grade and was correlated with tumor weight. Furthermore, Adamts $1^{+/-}$littermates showed intermediate primary tumor and metastatic burden, suggesting that tumor progression is sensitive to ADAMTS1 gene dosage. ADAMTS1 abundance was elevated only after 16 weeks of age, which confirms the notion that up-regulation of Adamts1 is not via direct activation of transcription by the middle-T oncogene. As has been demonstrated in human cancers, most likely Adamts 1 becomes transcriptionally activated through epigenetic mechanisms, including DNA methylation (colon and lung cancer) ${ }^{38}$ and histone acetylation (lung carcinoma). ${ }^{39}$

The reduced histological grade of invasive tumors and increased proportion of DCIS in Adamts $1^{-1-}$ mice are indicative of arrest or delayed disease progression in the absence of ADAMTS1. The higher proportion of noninvasive DCIS may indicate impaired capacity of tumor cells to break through the ductal basement membrane. Consistent with this, growing ovarian follicles in Adamts $1^{-1-}$ mice have defective basement membrane remodeling. ${ }^{3,31}$ The reduced size and proportion of aggressive tumors in Adamts $1^{-1-}$ mice may be due to a similar failure to degrade the ECM.

Angiogenesis is a key mechanism involved in tumor growth and metastasis, in which the protease ADAMTS1 may be involved. ${ }^{40-42}$ Our present results show no significant increase in blood vessel density in Adamts $1^{-1-}$ tumors, suggesting that antiangiogenic action of ADAMTS1 is not a major contributing factor to total tumor angiogenesis. Lymphangiogenesis in the ovary is dependent on ADAMTS1 activity, ${ }^{3,43}$ and in breast cancers enhanced lymphangiogenesis provides a route for dissemination to lymph nodes and eventually metastasis to distal tissues such as lung. ${ }^{44}$ Although we found the lowest proportion of lymph node metastases in Adamts $1^{-1-}$ mice, the infrequency of lymph node metastases of PyMT tumors (consistent with previous reports ${ }^{45}$ ) precludes any interpretation of a role for ADAMTS1 in dissemination to lymph nodes.

Our results are also consistent with observations from xenografted TA3 breast cancer cell lines overexpressing ADAMTS1, which showed reduced apoptosis and equivalent proliferation in pulmonary lesions. ${ }^{19}$ This activity was dependent on protease activity of ADAMTS1, which also mediated activation of the cell surface EGF-like ligands amphiregulin and heparin binding-EGF. A similar mechanism was demonstrated by overexpression of both MMP1 and ADAMTS1 proteases in weakly metastatic MDA-MB231 breast cancer sublines, resulting in augmented paracrine release of EGF-like ligands and enhanced bone metastasis. ${ }^{46}$ In PyMT $^{+}$mammary tumors, the apoptotic index was lower in Adamts $1^{+/+}$than in Adamts $1^{-1-}$ tumors, despite equivalent vascular density and cleaved versican accumulated in peritumoral stroma. The liberated G3 domain of cleaved versican has EGF-like activity ${ }^{47-49}$ and might act as an EGF-like signal in the Adamts $1^{+/+}$tumor microenvironment, resulting in reduced apoptosis and increased tumor growth compared with null littermates.

Versican abundance is a strong predictor of metastatic relapse in human breast cancer ${ }^{21,22}$ and in many other carcinoma types. ${ }^{23}$ Cleavage of versican by ADAMTS proteases is a context-dependent morphogenic signal, ${ }^{25,26}$ and N-terminal (G1) and C-terminal (G3) versican fragments enhance tumor growth, invasiveness, and metastasis. ${ }^{48,50-53}$ The local accumulation of versican fragments generated by ADAMTS1 digestion may promote cancer cell motility and invasion. This notion is supported by recent studies of glioma cells showing that the $\mathrm{G} 1$ domain of brevican generated by ADAMTS cleavage is capable of enhancing cell adhesion and motility. ${ }^{54,55}$ Furthermore, TGF $\beta 2$-stimulated glioma cell migration was completely blocked by an antibody specific to the ADAMTS-cleaved neo-epitope of VON1 versican (amino acid sequence DPEAAE). ${ }^{56}$ These findings from glioma progression underscore the important functional implications of proteoglycan processing by ADAMTS proteases in the progression to invasive metastatic cancer.

Human breast cancers interact with the immune system and become infiltrated by innate and adaptive immune cells that exert either antitumor or tumor-potentiating activity, depending on the type of immune response elicited (Th1 versus Th2). ${ }^{57}$ In the PyMT model, metastatic progression requires $\mathrm{CD} 4^{+} \mathrm{T}$ helper-2 (Th2, tolerogenic) cells that activate tumor promoting macrophages. ${ }^{58} \mathrm{~A}$ polarized Th1 (cytotoxic) response in T cells activates the M1 macrophage phenotype and immune rejection of tumors. ${ }^{57}$ Adamts $1^{-1-}$ tumors had increased $\mathrm{CD} 45^{+}$and $\mathrm{IL}-12^{+}$cell density and elevated mRNA for CD4OL (a Th1 co-stimulatory signal), and for SOCS2 and Tbet (signal transduction factors that promote cytotoxic Th1 cell differentiation), as well as elevated expression of IL-12 (a Th1-mediating cytokine) and of the cytolytic enzyme granzyme B. Taken together, these results indicate an enhanced cytotoxic host response in ADAMTS1-deficient tumors, a potential cause of heightened apoptosis and reduced tumor growth and metastasis. Accumulation of cleaved versican in Adamts $1^{+/+}$tumors may help to polarize a tumor-promoting immune response, as reported in Lewis lung carcinoma, in which tumor-derived versican interacting with Toll-like receptor 2 (TLR2) on immune cells is required for establishment of tumor foci in lungs. ${ }^{59}$

The present study provides in vivo evidence that ADAMTS1 plays a nonredundant role in growth and metastasis of mammary cancers. Lung metastasis in the PyMT mouse model is associated with spontaneously increased levels of ADAMTS1. In the presence of ADAMTS1-cleaved versican accumulated in the peritumoral stroma, tumor cell apoptosis was reduced and tumor grade and metastatic burden were increased. Our findings indicate that ADAMTS1 participates in tumormediated stromal remodeling important for the progression of DCIS to invasive disease and the development of metastatic disease, possibly by helping to deviate the 
host response and prevent cytotoxic immune attack of the tumor.

\section{Acknowledgments}

We thank Hannah Brown, Miranda Ween, and Lisa Akison for assistance in tumor dissection and genotyping.

\section{References}

1. Apte SS: A disintegrin-like and metalloprotease (reprolysin-type) with thrombospondin type 1 motif (ADAMTS) superfamily: functions and mechanisms. J Biol Chem 2009, 284:31493-31497

2. Kuno K, Kanada N, Nakashima E, Fujiki F, Ichimura F, Matsushima K: Molecular cloning of a gene encoding a new type of metalloproteinase-disintegrin family protein with thrombospondin motifs as an inflammation associated gene. J Biol Chem 1997, 272:556-562

3. Brown HM, Dunning KR, Robker RL, Pritchard M, Russell DL: Requirement for ADAMTS- 1 in extracellular matrix remodeling during ovarian folliculogenesis and lymphangiogenesis. Dev Biol 2006, 300: 699-709

4. Russell DL, Doyle KM, Ochsner SA, Sandy JD, Richards JS: Processing and localization of ADAMTS-1 and proteolytic cleavage of versican during cumulus matrix expansion and ovulation. J Biol Chem 2003, 278:42330-42339

5. Mittaz L, Russell DL, Wilson T, Brasted M, Tkalcevic J, Salamonsen LA, Hertzog PJ, Pritchard MA: Adamts-1 is essential for the development and function of the urogenital system. Biol Reprod 2004, 70: 1096-1105

6. Rehn AP, Birch MA, Karlström E, Wendel M, Lind T: ADAMTS-1 increases the three-dimensional growth of osteoblasts through type I collagen processing. Bone 2007, 41:231-238

7. Canals F, Colomé N, Ferrer C, Plaza-Calonge Mdel C, RodríguezManzaneque JC: Identification of substrates of the extracellular protease ADAMTS1 by DIGE proteomic analysis. Proteomics 2006, 6 Suppl 1:S28-S35

8. Rodríguez-Manzaneque JC, Carpizo D, Plaza-Calonge MD, TorresCollado AX, Thai SN, Simons M, Horowitz A, Iruela-Arispe ML: Cleavage of syndecan-4 by ADAMTS1 provokes defects in adhesion. Int J Biochem Cell Biol 2008

9. Sandy JD, Westling J, Kenagy RD, Iruela-Arispe ML, Verscharen C, Rodriguez-Mazaneque JC, Zimmermann DR, Lemire JM, Fischer JW, Wight TN, Clowes AW: Versican V1 proteolysis in human aorta in vivo occurs at the Glu441-Ala442 bond, a site that is cleaved by recombinant ADAMTS-1 and ADAMTS-4. J Biol Chem 2001, 276:1337213378

10. Rodríuez-Manzaneque JC, Westling J, Thai SN, Luque A, Knauper V, Murphy G, Sandy JD, Iruela-Arispe ML: ADAMTS1 cleaves aggrecan at multiple sites and is differentially inhibited by metalloproteinase inhibitors. Biochem Biophys Res Commun 2002, 293:501-508

11. Krampert M, Kuenzle S, Thai SN, Lee N, Iruela-Arispe ML, Werner S: ADAMTS1 proteinase is up-regulated in wounded skin and regulates migration of fibroblasts and endothelial cells. J Biol Chem 2005, 280:23844-23852

12. Su SC, Mendoza EA, Kwak HI, Bayless KJ: Molecular profile of endothelial invasion of three-dimensional collagen matrices: insights into angiogenic sprout induction in wound healing. Am J Physiol Cell Physiol 2008, 295:C1215-C1229

13. Stankunas K, Hang CT, Tsun ZY, Chen H, Lee NV, Wu JI, Shang C, Bayle JH, Shou W, Iruela-Arispe ML, Chang CP: Endocardial Brg1 represses ADAMTS1 to maintain the microenvironment for myocardial morphogenesis. Dev Cell 2008, 14:298-311

14. Kang Y, Siegel PM, Shu W, Drobnjak M, Kakonen SM, Cordón-Cardo $\mathrm{C}$, Guise TA, Massagué J: A multigenic program mediating breast cancer metastasis to bone. Cancer Cell 2003, 3:537-549

15. Han HJ, Russo J, Kohwi Y, Kohwi-Shigematsu T: SATB1 reprogrammes gene expression to promote breast tumour growth and metastasis. Nature 2008, 452:187-193

16. Minn AJ, Kang Y, Serganova I, Gupta GP, Giri DD, Doubrovin M, Ponomarev V, Gerald WL, Blasberg R, Massagué J: Distinct organ- specific metastatic potential of individual breast cancer cells and primary tumors. J Clin Invest 2005, 115:44-55

17. Masui T, Hosotani R, Tsuji S, Miyamoto Y, Yasuda S, Ida J, Nakajima S, Kawaguchi M, Kobayashi H, Koizumi M, Toyoda E, Tulachan S, Arii S, Doi R, Imamura M: Expression of METH-1 and METH-2 in pancreatic cancer. Clin Cancer Res 2001, 7:3437-3443

18. Kuno K, Bannai K, Hakozaki M, Matsushima K, Hirose K: The carboxyl-terminal half region of ADAMTS-1 suppresses both tumorigenicity and experimental tumor metastatic potential. Biochem Biophys Res Commun 2004, 319:1327-1333

19. Liu YJ, Xu Y, Yu Q: Full-length ADAMTS-1 and the ADAMTS-1 fragments display pro- and antimetastatic activity, respectively. Oncogene 2006, 25:2452-2467

20. Ricciardelli C, Mayne K, Sykes PJ, Raymond WA, McCaul K, Marshall VR, Horsfall DJ: Elevated levels of versican but not decorin predict disease progression in early-stage prostate cancer. Clin Cancer Res 1998, 4:963-971

21. Ricciardelli C, Brooks JH, Suwiwat S, Sakko AJ, Mayne K, Raymond WA, Seshadri R, LeBaron RG, Horsfall DJ: Regulation of stromal versican expression by breast cancer cells and importance to relapse-free survival in patients with node-negative primary breast cancer. Clin Cancer Res 2002, 8:1054-1060

22. Suwiwat S, Ricciardelli C, Tammi R, Tammi M, Auvinen P, Kosma VM, LeBaron RG, Raymond WA, Tilley WD, Horsfall DJ: Expression of extracellular matrix components versican, chondroitin sulfate, tenascin, and hyaluronan, and their association with disease outcome in node-negative breast cancer. Clin Cancer Res 2004, 10:2491-2498

23. Ricciardelli C, Sakko AJ, Ween MP, Russell DL, Horsfall DJ: The biological role and regulation of versican levels in cancer. Cancer Metastasis Rev 2009

24. Kern CB, Norris RA, Thompson RP, Argraves WS, Fairey SE, Reyes L, Hoffman S, Markwald RR, Mjaatvedt CH: Versican proteolysis mediates myocardial regression during outflow tract development [Erratum appeared in Dev Dyn 2007;236:1157]. Dev Dyn 2007, 236:671683

25. McCulloch DR, Nelson CM, Dixon LJ, Silver DL, Wylie JD, Lindner V, Sasaki T, Cooley MA, Argraves WS, Apte SS: ADAMTS metalloproteases generate active versican fragments that regulate interdigital web regression. Dev Cell 2009, 17:687-698

26. Enomoto H, Nelson CM, Somerville RP, Mielke K, Dixon LJ, Powell K, Apte SS: Cooperation of two ADAMTS metalloproteases in closure of the mouse palate identifies a requirement for versican proteolysis in regulating palatal mesenchyme proliferation. Development 2010, 137:4029-4038

27. Qiu TH, Chandramouli GV, Hunter KW, Alkharouf NW, Green JE, Liu ET: Global expression profiling identifies signatures of tumor virulence in MMTV-PyMT-transgenic mice: correlation to human disease. Cancer Res 2004, 64:5973-5981

28. Lim E, Wu D, Pal B, Bouras T, Asselin-Labat ML, Vaillant F, Yagita $H$, Lindeman GJ, Smyth GK, Visvader JE: Transcriptome analyses of mouse and human mammary cell subpopulations reveal multiple conserved genes and pathways. Breast Cancer Res 2010, 12:R21

29. Ricciardelli C, Jackson MW, Choong CS, Stahl J, Marshall VR, Horsfall DJ, Tilley WD: Elevated levels of HER-2/neu and androgen receptor in clinically localized prostate cancer identifies metastatic potential. Prostate 2008, 68:830-838

30. Russell DL, Ochsner SA, Hsieh M, Mulders S, Richards JS: Hormoneregulated expression and localization of versican in the rodent ovary. Endocrinology 2003, 144:1020-1031

31. Brown HM, Dunning KR, Robker RL, Boerboom D, Pritchard M, Lane M, Russell DL: ADAMTS1 cleavage of versican mediates essential structural remodeling of the ovarian follicle and cumulus-oocyte matrix during ovulation in mice. Biol Reprod 2010, 83:549-557

32. Dunning KR, Lane M, Brown HM, Yeo C, Robker RL, Russell DL Altered composition of the cumulus-oocyte complex matrix during in vitro maturation of oocytes. Hum Reprod 2007, 22:2842-2850

33. Tuxhorn JA, Ayala GE, Smith MJ, Smith VC, Dang TD, Rowley DR: Reactive stroma in human prostate cancer: induction of myofibroblast phenotype and extracellular matrix remodeling. Clin Cancer Res 2002, 8:2912-2923

34. Koyama H, Kobayashi N, Harada M, Takeoka M, Kawai Y, Sano K, Fujimori M, Amano J, Ohhashi T, Kannagi R, Kimata K, Taniguchi S, Itano N: Significance of tumor-associated stroma in promotion of 
intratumoral lymphangiogenesis: pivotal role of a hyaluronan-rich tumor microenvironment. Am J Pathol 2008, 172:179-193

35. Rocks N, Paulissen G, Quesada-Calvo F, Munaut C, Gonzalez ML, Gueders M, Hacha J, Gilles C, Foidart JM, Noel A, Cataldo DD: ADAMTS-1 metalloproteinase promotes tumor development through the induction of a stromal reaction in vivo. Cancer Res 2008, 68:95419550

36. Lorusso G, Rüegg C: The tumor microenvironment and its contribution to tumor evolution toward metastasis. Histochem Cell Biol 2008 , 130:1091-1103

37. Sahai E: Illuminating the metastatic process. Nat Rev Cancer 2007 , 7:737-749

38. Choi JE, Kim DS, Kim EJ, Chae MH, Cha SI, Kim CH, Jheon S, Jung TH, Park JY: Aberrant methylation of ADAMTS1 in non-small cell lung cancer. Cancer Genet Cytogenet 2008, 187:80-84

39. Chou CW, Chen CC: HDAC inhibition upregulates the expression of angiostatic ADAMTS1. FEBS Lett 2008, 582:4059-4065

40. Luque A, Carpizo DR, Iruela-Arispe ML: ADAMTS1/METH1 inhibits endothelial cell proliferation by direct binding and sequestration of VEGF165. J Biol Chem 2003, 278:23656-23665

41. Gustavsson H, Jennbacken K, Welén K, Damber JE: Altered expression of genes regulating angiogenesis in experimental androgenindependent prostate cancer. Prostate 2008, 68:161-170

42. Jönsson-Rylander AC, Nilsson T, Fritsche-Danielson R, Hammarström A, Behrendt M, Andersson JO, Lindgren K, Andersson AK, Wallbrandt $P$, Rosengren B, Brodin P, Thelin A, Westin A, HurtCamejo E, Lee-Søgaard CH: Role of ADAMTS-1 in atherosclerosis: remodeling of carotid artery, immunohistochemistry, and proteolysis of versican. Arterioscler Thromb Vasc Biol 2005, 25:180-185

43. Brown HM, Robker RL, Russell DL: Development and hormonal regulation of the ovarian Iymphatic vasculature. Endocrinology 2010 151:5446-5455

44. Mumprecht V, Detmar M: Lymphangiogenesis and cancer metastasis. J Cell Mol Med 2009, 13:1405-1416

45. Almholt K, Lund LR, Rygaard J, Nielsen BS, Dano K, Rømer J, Johnsen M: Reduced metastasis of transgenic mammary cancer in urokinase-deficient mice. Int J Cancer 2005, 113:525-532

46. Lu X, Wang Q, Hu G, Van Poznak C, Fleisher M, Reiss M, Massagué J, Kang Y: ADAMTS1 and MMP1 proteolytically engage EGF-like ligands in an osteolytic signaling cascade for bone metastasis. Genes Dev 2009, 23:1882-1894
47. Zhang Y, Cao L, Yang BL, Yang BB: The G3 domain of versican enhances cell proliferation via epidermial growth factor-like motifs. J Biol Chem 1998, 273:21342-21351

48. Zheng PS, Wen J, Ang LC, Sheng W, Viloria-Petit A, Wang Y, Wu Y, Kerbel RS, Yang BB: Versican/PG-M G3 domain promotes tumor growth and angiogenesis. FASEB J 2004, 18:754-756

49. Wu YJ, La Pierre DP, Wu J, Yee AJ, Yang BB: The interaction of versican with its binding partners. Cell Res 2005, 15:483-494

50. Yee AJ, Akens M, Yang BL, Finkelstein J, Zheng PS, Deng Z, Yang B: The effect of versican G3 domain on local breast cancer invasiveness and bony metastasis. Breast Cancer Res 2007, 9:R47

51. Ang LC, Zhang Y, Cao L, Yang BL, Young B, Kiani C, Lee V, Allan K, Yang BB: Versican enhances locomotion of astrocytoma cells and reduces cell adhesion through its G1 domain. J Neuropathol Exp Neurol 1999, 58:597-605

52. Cattaruzza S, Schiappacassi M, Kimata K, Colombatti A, Perris R: The globular domains of PG-M/versican modulate the proliferation-apoptosis equilibrium and invasive capabilities of tumor cells. FASEB J 2004, 18:779-781

53. Paris S, Sesboüé R, Chauzy C, Maingonnat C, Delpech B: Hyaluronectin modulation of lung metastasis in nude mice. Eur $\mathrm{J}$ Cancer 2006, 42:3253-3259

54. Viapiano MS, Hockfield S, Matthews RT: BEHAB/brevican requires ADAMTS-mediated proteolytic cleavage to promote glioma invasion. J Neurooncol 2008, 88:261-272

55. Hu B, Kong LL, Matthews RT, Viapiano MS: The proteoglycan brevican binds to fibronectin after proteolytic cleavage and promotes glioma cell motility. J Biol Chem 2008, 283:24848-24859

56. Arslan F, Bosserhoff AK, Nickl-Jockschat T, Doerfelt A, Bogdahn U, Hau $P$ : The role of versican isoforms V0/N1 in glioma migration mediated by transforming growth factor-beta2. Br J Cancer 2007, 96 1560-1568

57. DeNardo DG, Coussens LM: Inflammation and breast cancer. Balancing immune response: crosstalk between adaptive and innate immune cells during breast cancer progression, Breast Cancer Res 2007, 9:212

58. DeNardo DG, Barreto JB, Andreu P, Vasquez L, Tawfik D, Kolhatkar $\mathrm{N}$, Coussens LM: CD4(+) T cells regulate pulmonary metastasis of mammary carcinomas by enhancing protumor properties of macrophages. Cancer Cell 2009, 16:91-102

59. Kim S, Takahashi H, Lin WW, Descargues P, Grivennikov S, Kim Y Luo JL, Karin M: Carcinoma-produced factors activate myeloid cells through TLR2 to stimulate metastasis. Nature 2009, 457:102-106 